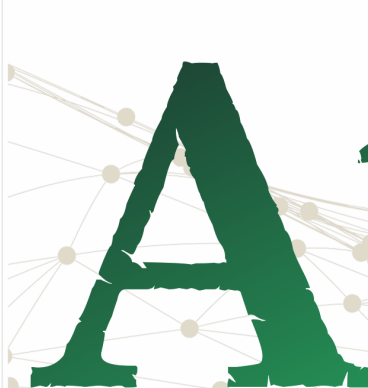

ISSN No 2526-8031

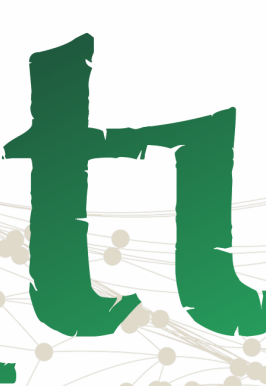

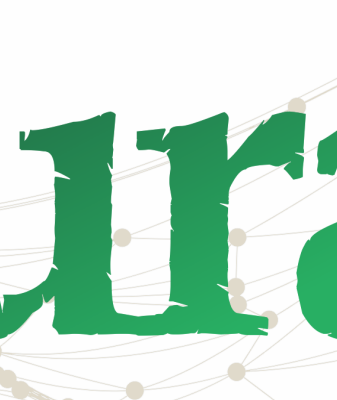

á

Pan-Amazônica

de Comunicação

Vol. 3, n. 2, Mai-Ago. 2019

\title{
ANÁLISE DA SENSIBILIZAÇÃO DO JORNALISMO AMBIENTAL EM RIO GRANDE DO NORTE
}

Analysis of the Sensibilization of Environmental Journalism in Rio Grande Do Norte

Análisis de la Sensibilización del Periodismo Ambiental en Rio Grande Do Norte

\author{
Nicole Bernardes Baracho ${ }^{1}$ \\ Grace Soares Costa ${ }^{2} 3$
}

\section{RESUMO}

Este artigo apresenta alguns dos resultados obtidos no projeto de pesquisa que analisa a qualificação da cobertura jornalística da região sobre meio ambiente e ciência do jornal "Tribuna do Norte" (Natal/RN - http://www.tribunadonorte.com.br/), considerando a periodicidade que estas reportagens são publicadas e os critérios gerais do jornalismo e de seus gêneros científico e ambiental. O objetivo foi avaliar se a imprensa local informou eficientemente o seu público sobre as questões ambientais e suas consequências na região Nordeste. Assim, a partir da avaliação dos resultados, busca-se contribuir com a qualificação do conhecimento e informação que são repassados para o público leitor, de forma que possam tomar decisões esclarecidas sobre a temática.

PALAVRAS-CHAVE: Tribuna do Norte; Jornalismo Ambiental; Meio ambiente.

\footnotetext{
${ }^{1}$ Graduanda em Comunicação Social/Jornalismo da Universidade Federal do Amazonas. E-mail: nicolebaracho@hotmail.com

2 Mestre em Sociedade e Cultura na Amazônia pela Universidade Federal do Amazonas, bacharel em Comunicação Social/Jornalismo (UFAM). Professora do curso de Jornalismo da UFAM e membro do corpo editorial da revista FMF (Manaus). Tem experiência na área de comunicação, com ênfase em Jornalismo Científico. E-mail: grace.soares@gmail.com

3 Endereço de contato dos autores (por correio): Av. General Rodrigo Octavio Jordão Ramos, 1200 - Coroado I, Manaus, CEP: 69067-005, Brasil.
} 


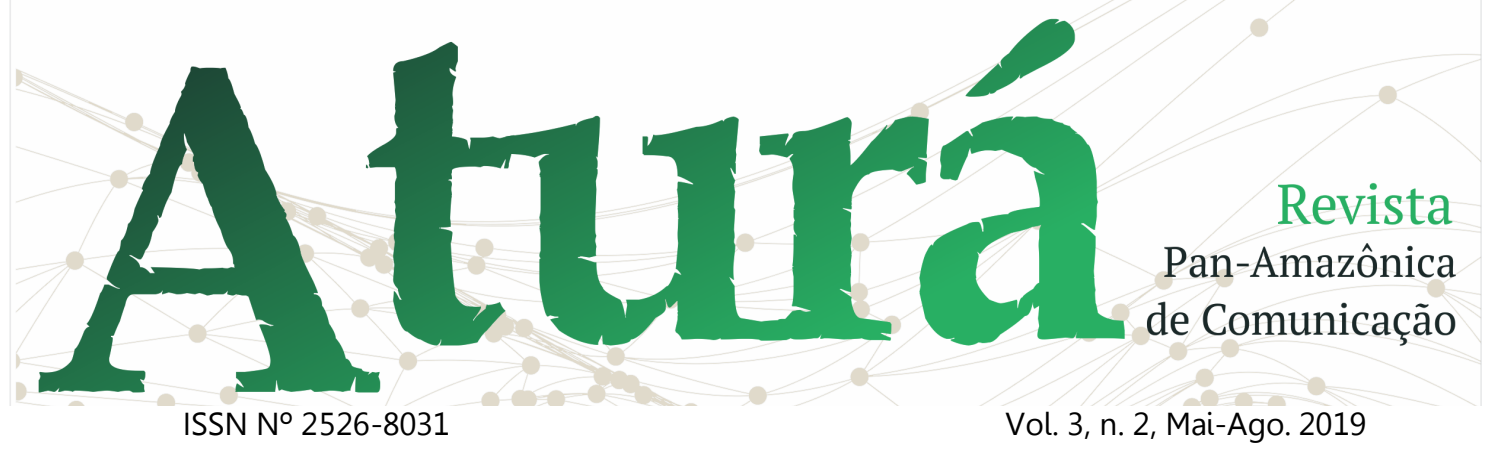

\begin{abstract}
This article presents some of the results obtained in the research project that analyses the qualification of the journalistic coverage in the region about environment and science in the journal "Tribuna do Norte" (Natal/RN - http://www.tribunadonorte.com.br/), considering the periodicity in which these reports are published and the general criteria of journalism and its scientific and environmental genders. The goal was to evaluate if the local press efficiently informed its public about the environmental issues and its consequences in the Northeast region. Thus, from the evaluation of the results, we seek to contribute with the qualification of the knowledge and information that are passed on to the reading public, so that they can make enlightened decisions about the subject.
\end{abstract}

KEYWORDS: Tribuna do Norte; Environmental Journalism; Environment.

\title{
RESUMEN
}

Este artículo presenta algunos de los resultados obtenidos en el proyecto de pesquisa que estudia la calificación de la cobertura periodística de la región respecto al medio ambiente y ciencia del periódico "Tribuna do Norte" (Natal/RN http://www.tribunadonorte.com.br/), llevando en cuenta la periodicidad en que estos repostajes son publicados y los criterios generales del periodismo y sus géneros cientifico y ambiental. El objetivo fue lo de evaluar si la imprenta local le informó a su publico de modo efectivo las cuestiones ambientales y sus consecuencias en la región Noreste. Así siendo, a partir de la evaluación de los resultados, se busca contribuir con la calificación del conocimiento y información que son repasados al público lector, de forma que puedan tomar decisiones aclaradas sobre el tema.

PALABRAS CLAVE: Tribuna do Norte; Periodismo Ambiental; Medio ambiente.

Recebido em: 24.02.2019. Aceito em: 24.04.2019. Publicado em: 01.05.2019. 


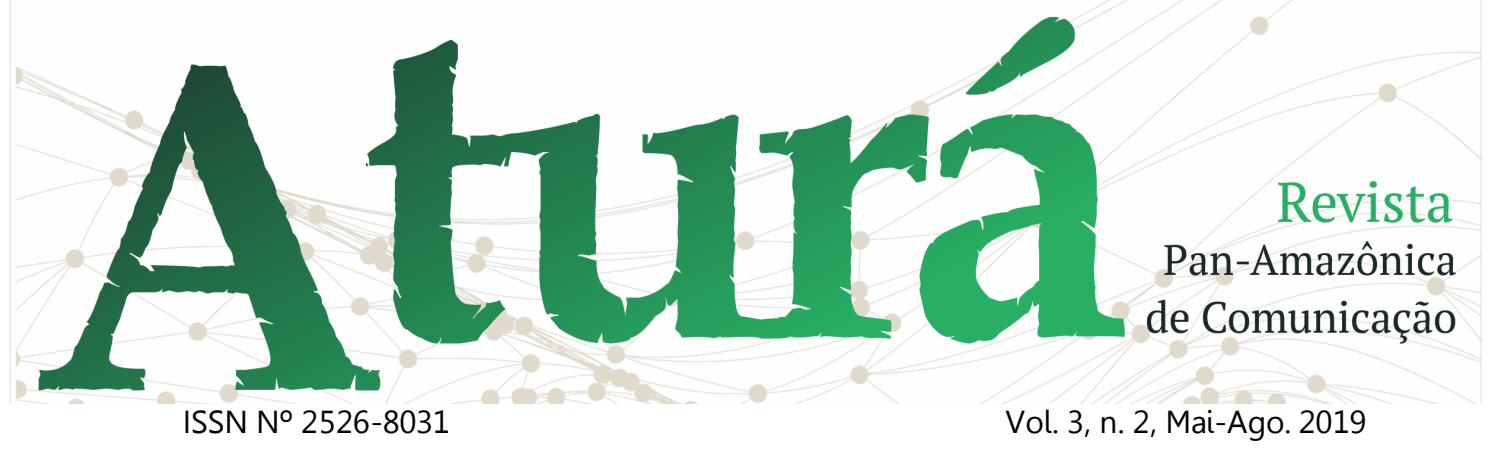

\section{Introdução}

Esta pesquisa teve como propósito análise de notícias com a temática ambiental no jornal "Tribuna do Norte", situado na cidade de Natal no estado do Rio Grande do Norte. A finalidade foi constatar se a informação ambiental e científica passada aos cidadãos da região durante o período de setembro de 2017 a março de 2018 foi de qualidade e se a imprensa contribuiu para a conscientização de problemas ambientais e seus efeitos colaterais.

Utilizou-se estruturas teóricas e metodológicas de áreas convergentes como a Ciência Política, Ética Ambiental, Jornalismo, Comunicação e Sociologia para atribuir uma resposta à questão apresentada. Sendo assim, acredita-se que investigar o papel da mídia na conciliação do progresso e meio ambiente significa contribuir para qualificar o papel dos veículos de comunicação na questão ambiental e melhorar o nível de informação dos cidadãos. E quando se fala da região Nordeste tem-se uma proporção única, já que é um território castigado pela intensa seca por longos períodos de tempo.

Desde a implantação do modelo econômico capitalista na Revolução Industrial, percebe-se o crescente descaso da população mundial diante de questões ambientais. Os seres humanos se veem perante a real possibilidade de suas decisões relacionadas à exploração insustentável dos recursos naturais causarem sua extinção, levando a consequências catastróficas como mudanças climáticas, enchentes, grandes estiagens, desertificação, extinção de espécies da fauna e flora, entre outros tão inquietantes quanto. De acordo com Leff (2009, p. 47), a crise ambiental não só se manifesta na destruição do meio físico e biológico, mas também na degradação da qualidade de vida, tanto no âmbito rural como no urbano.

O maior pretexto que leva o governo a não amparar claramente um modelo econômico e social que harmonize progresso e o uso sustentável dos recursos naturais é baseado na falta de apoio da opinião pública de seus referentes países, estados e município a normas que originarão mudanças nas relações de consumo e nos processos de produção. Sendo assim, pode-se dizer que há uma dependência diretamente proporcional do nível de informação científica sobre as questões ambientais e a tomada de decisões elucidadas sobre a adesão ou não das medidas necessárias para que haja a diminuição do aquecimento global com a efetiva ação do governo. 


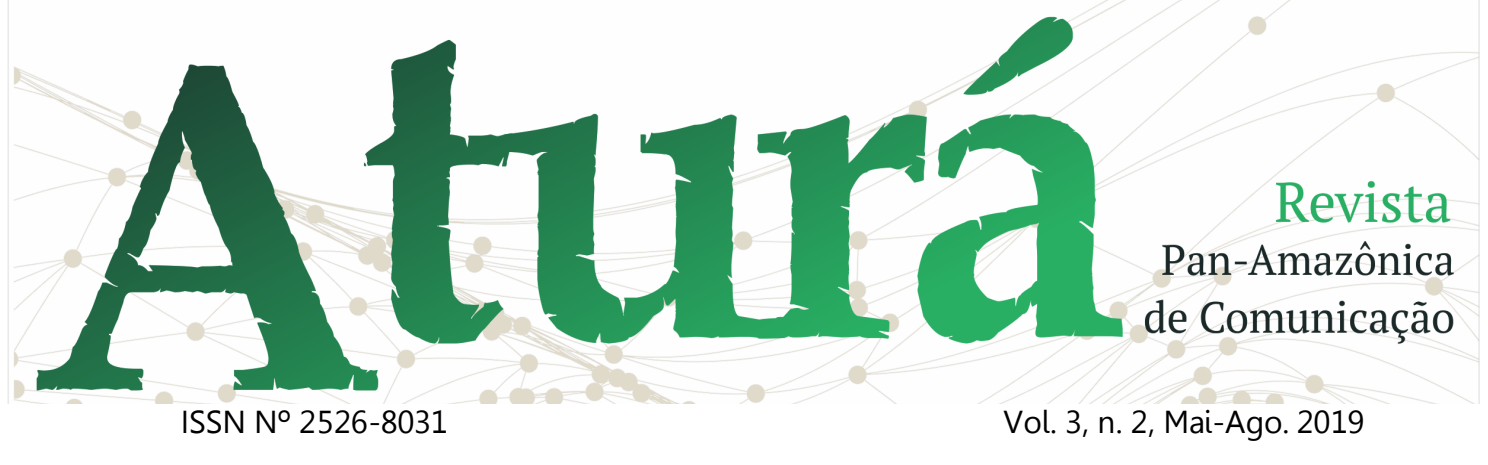

\section{Fundamentação teórica}

Fez-se uso da proposta de Kovach e Rosenstiel (2003) que, após trezentas entrevistas com jornalistas, elaboraram uma lista com nove princípios que possibilitam ao jornalismo alcançar seu propósito. Além do trabalho dos autores, também acrescentamos contribuições teóricas de pesquisadores brasileiros da área.

Compromisso com a verdade: De acordo com os conceitos de Kovack e Rosenstiel (2003), a verdade jornalística é diferente da verdade filosófica, uma vez que a primeira é construída progressivamente, reportagem a reportagem. As pessoas "carecem de síntese e verificação, ou seja, de informações claras, diretas e exatas (verdadeiras), que conduzam a um entendimento do fato" (Kovack; Rosenstiel, 2003, p.125) e não precisam de mais contextos e interpretação no relato jornalístico. Para Pena (2005), o primeiro compromisso do jornalismo deve ser com a verdade.

Lealdade ao interesse público: Chamamos de independência jornalística o fato de o jornalismo ser financiado pelo setor privado, mas servir aos interesses públicos (KOVACH; ROSENSTIEL, 2003). Falando-se sobre o modo capitalista de produção, os jornalistas são empregados do capital, ou seja, das empresas privadas que enxergam a produção e divulgação de informações como um negócio gerador de renda. Em parte, isto não está errado, entretanto, podemos fazer uma ponderação voltada ao item anterior, relacionado ao compromisso com a verdade. A obrigação social do jornalista o leva além dos interesses imediatos de seus patrões e essa mesma obrigação torna-se pode impulsionar sucesso financeiro desses mesmos patrões.

A disciplina da verificação: Ao se comprometer com a verdade, faz-se necessário que o jornalista verifique as informações publicadas. A disciplina da verificação separa o jornalismo do entretenimento, propaganda, literatura ou arte (KOVACK; ROSENSTIEL, 2003). Ainda, Chaparro (2001) chama atenção para o fato de que tem ocorrido com certa frequência no atual jornalismo, inundado de acontecimentos planejados e controlados por agentes tão competentes quanto interessados, a renúncia dos repórteres à sua função investigativa e crítica.

Independência das fontes: A organização e a capacitação discursiva das fontes é a mais importante modificação ocorrida nos processos jornalísticos nos últimos quarenta anos, de acordo com Chaparro (2001). Trata-se de uma questão de bom senso e de um compromisso inabalável com o princípio da lealdade com a população, em primeiro lugar, que irá evitar a 


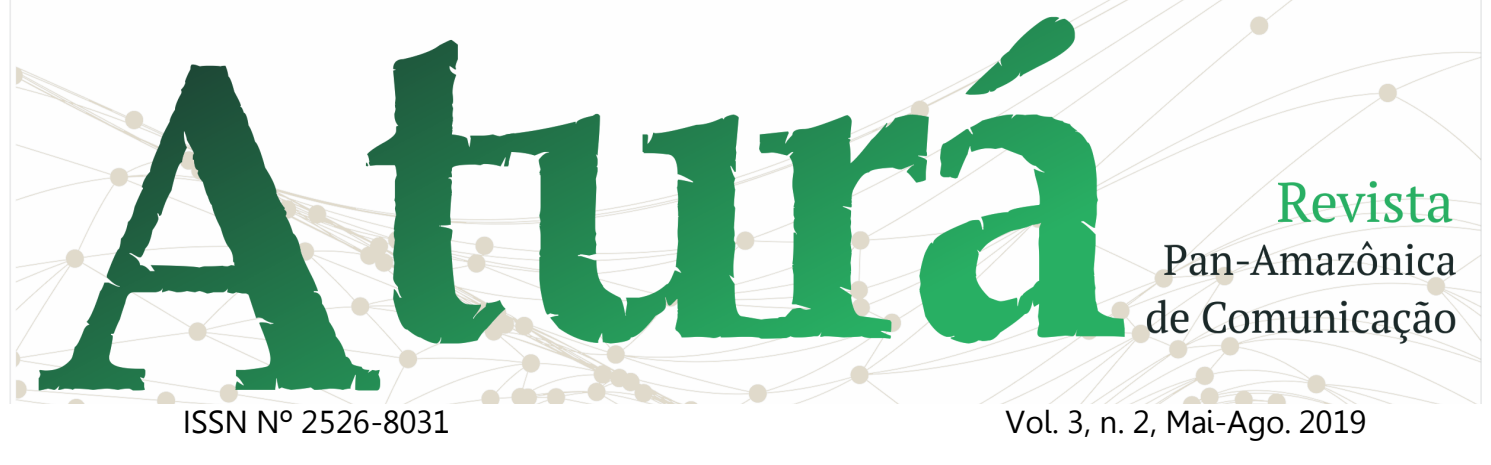

dependência das fontes e, portanto, separar o jornalismo do partidarismo. Proibições rigorosas não garantirão que um jornalista se abstenha de sua opinião e ideais, advertem Kovach e Rosenstiel (2003).

Ser um monitor independente do poder: Para Noblat (2004, p. 15), "não basta a um jornal ser independente. Os leitores esperam que ele sirva à comunidade onde circula atuando como um implacável fiscal dos atos dos poderes público e privado". O princípio de guardião do interesse público do jornalismo se aplica tanto às ações do governo quanto aquelas das demais instituições poderosas da sociedade (KOVACH; ROSENSTIEL, 2003). É dever dos jornalistas romper com a concepção de bipolarização (jornalismo versus governos) dos conflitos do poder, pois há sempre um terceiro polo que precisa ser levado em consideração e ganhar identidade: o povo. De acordo com Chaparro (2001), "apesar de quase não entrar na pauta jornalística, o povo produz acontecimentos e com eles conflitos, cultura - fatos, falas, artes e saberes que precisam ser captados, compreendidos, narrados".

Promover um fórum para a crítica e o comentário do público: É importante o jornalismo funcione como um fórum de debate sobre o fato em questão. Para Kovach e Rosenstiel (2003), convém evitar abordar os lados extremos de um assunto, pois exclui a maioria dos cidadãos e dificilmente são conciliatórios. Além disso, é de suma importância que estas discussões estejam voltadas a todas as classes sociais, de forma que a informação não se concentre num grupo fechado.

Apresentar o significativo de forma interessante e relevante: Este princípio é voltado para duas vertentes do trabalho jornalístico: a escolha das notícias que são significativas e a produção do texto de forma que torne as notícias interessantes. "O fato é que os jornalistas se valem de uma cultura própria para decidir o que é ou não é notícia. Ou seja, têm critérios próprios, que consideram óbvios, quase instintivos" (PENA, 2005, p.71).

O jornalista tem um dever com sua consciência: $\mathrm{O}$ jornalista deve perceber que tem uma responsabilidade em permitir que sua consciência tenha uma voz e fazer como que todos ao seu redor façam o mesmo. O último, porém não menos importante princípio, preconiza que todos os jornalistas - da redação à sala da diretoria - devem ter um sentido pessoal de ética e responsabilidade uma bússola moral (KOVACH; ROSENSTIEL, 2003). Além disso, Chaparro (2000) lembra que a sociedade espera do jornalismo $\circ$ relato verídico dos 


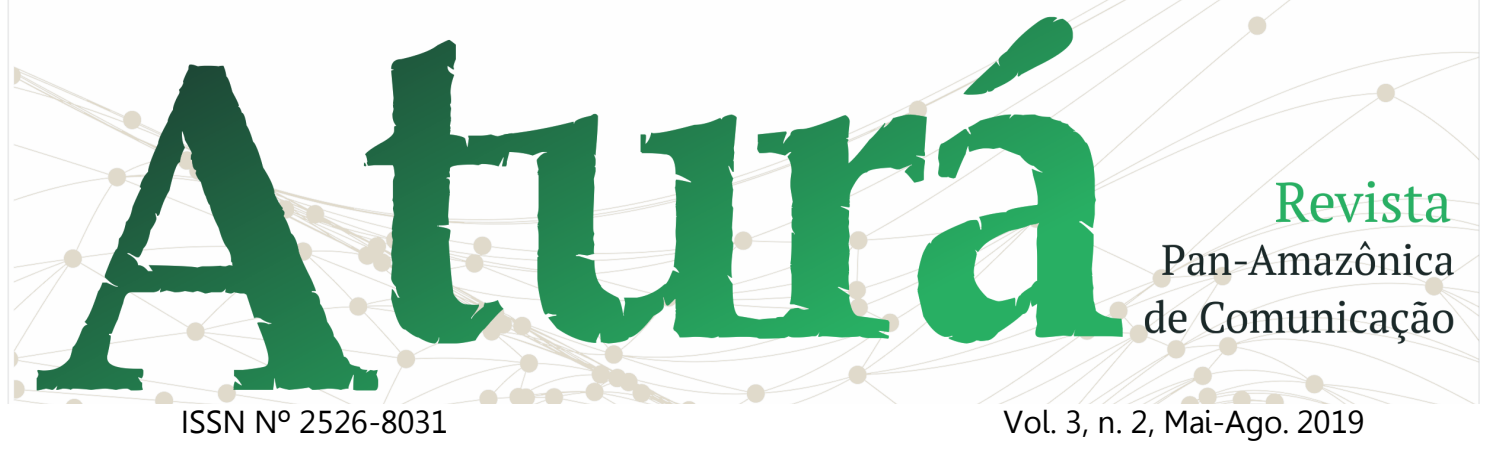

acontecimentos e a explicação isenta dos fatos e contextos.

Quando investigamos o papel do jornalismo na conciliação de progresso e meio ambiente, contribuímos para a qualificação do papel dos veículos de comunicação e na melhora do nível de informação do público. Esta situação nos destina ao jornalismo científico, uma vez que ele proporciona a divulgação da ciência e tecnologia, encaixadas nos critérios de produção jornalística, através dos meios de comunicação.

O jornalismo científico não apenas divulga ciência, mas também instiga discussões, traz reflexões e contribui para a formação de uma sociedade inclusa na cultura científica. Ivanissevich (2005) considera que cabe ao jornalismo científico possibilitar debates sobre questões polêmicas como a clonagem de embriões, alimentos transgênicos e mudanças climáticas globais. Essa função tem sustento nas responsabilidades éticas da mídia e também porque ao apelo popular que assegura a audiência e a venda da notícia. "Nesse sentido, a mídia tem um papel fundamental: o de manter as pessoas informadas sobre as novas conquistas científicas para que possam se posicionar diante delas" (IVANISSEVICH, 2005, p.25).

O autor Bueno (1984) afirma que o jornalismo científico acata seis funções: função informativa, função educativa, função social, função cultural, função econômica, função político-ideológica.

O papel social deste jornalismo ambiental é estar comprometido com a causa do desenvolvimento sustentável e com a melhoria da qualidade de vida das pessoas nos âmbitos político, social e cultural. Para Bueno (2007, p.29) "Só desta forma conseguirá encontrar forças para resistir às investidas e pressões de governos, empresas e até de universidades e institutos de pesquisa, muitos deles patrocinados ou reféns dos grandes interesses". A realização desta função prevê o cumprimento de alguns princípios e procedimentos que a comunidade jornalística do campo ambiental vem adotando ao longo dos anos.

Com o objetivo de analisar a cobertura jornalística sobre meio ambiente realizada pelo jornal online "Tribuna do Norte" (Natal/RN), efetivamos uma recapitulação da bibliografia produzida relativa a isso e ressaltamos os oito pontos convergentes apontados pelo autor Bueno (2007): as reportagens precisam apresentar diversidade de fontes, possuir independência em relação às fontes, abrir espaço para o debate, evitar o sensacionalismo. 


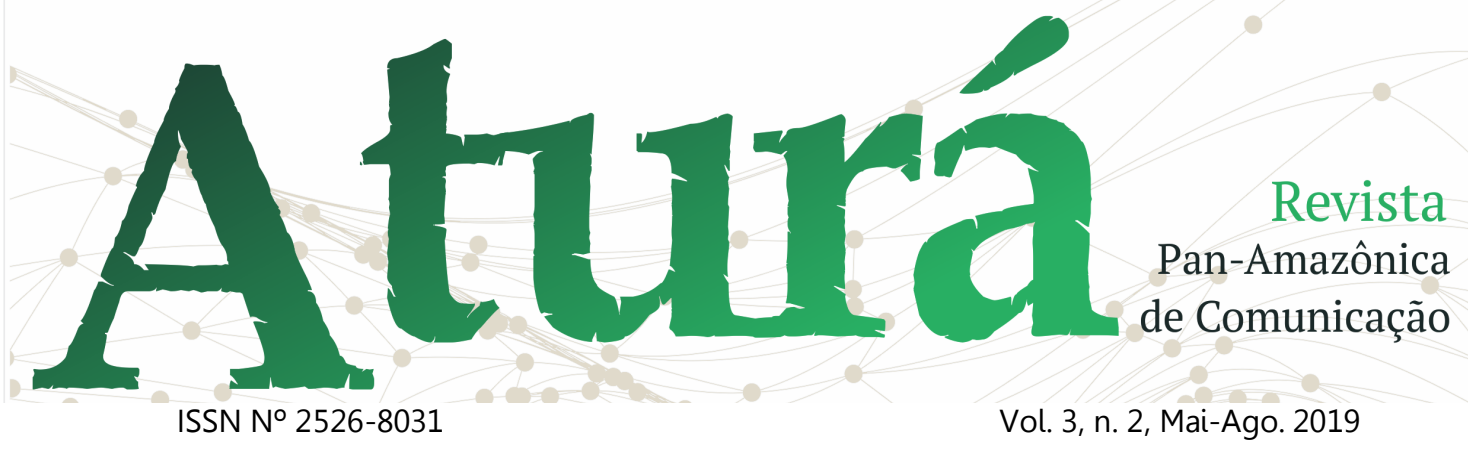

\section{Descrição metodológica}

A pesquisa fez uso de métodos qualitativos e quantitativos e lançou mão da análise de conteúdo, já que se apresenta como um dos métodos mais eficientes para rastrear informação dado a sua excelente capacidade de fazer interferências sobre aquilo que ficou impresso ou gravado (SANTOS, 1997).

Esta pesquisa fez uso de análise de conteúdo, pois é empregada para detectar tendências e modelos de análise de critérios de noticiabilidade, enquadramentos e agendamentos. Também é utilizada na descrição de produtos, gêneros e formatos jornalísticos para analisar características da produção de indivíduos, grupos e organizações, disparidades e para fazer uma comparação de conteúdo jornalístico de diferentes mídias em diferentes culturas.

A análise do conteúdo jornalístico publicado no jornal online "Tribuna do Norte" foi feita de acordo com os pressupostos mencionados acima e a escolha deste periódico diário deu-se pelo fato deste ter grande audiência em seu Estado. A metodologia consistiu na coleta de e análise de textos jornalísticos publicados entre setembro de 2017 a março de 2018 sobre problemas ambientais em Rio Grande do Norte com a finalidade de fazer inferências sobre seus conteúdos e formatos, ajustando-o em categorias de análise.

Os parâmetros utilizados para a seleção dos textos estão focados no aspecto de esses conterem referências a problemas ambientais e pertencerem ao gênero informativo do jornalismo em seus formatos notícia e reportagem descritos por Melo (2010). Além disso, todas as reportagens foram coletadas a partir das seguintes palavras-chave: seca, meio ambiente, água, escassez, crise hídrica, lixo, carros-pipa, estiagem, enchente, alagamento.

A ferramenta utilizada para escolher as categorias teve como normas os requisitos pressupostos por Bardin (2010). Com o objetivo da análise já definido, é significativo determinar o corpus da pesquisa (citado no parágrafo anterior) e a escolha das categorias de análise baseadas nas normas do jornalismo e de seus gêneros científico e ambiental.

A seleção das categorias teve também como base as seguintes proposições: a exclusão mútua (um elemento não pode ser classificado em duas ou mais categorias), a homogeneidade (num mesmo conjunto categorial só pode funcionar com uma dimensão de análise), a pertinência (as categorias deveriam estar adaptadas ao material de análise escolhido e pertencente ao quadro teórico escolhido), 


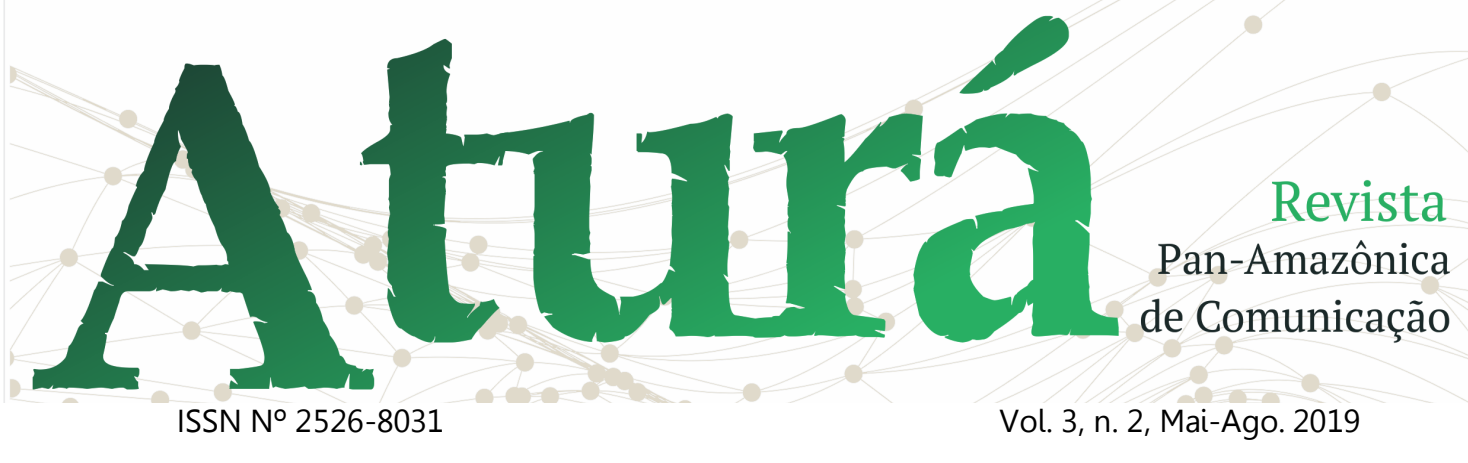

a objetividade e fidelidade (as diferentes partes de um mesmo material analisado devem ser codificadas da mesma maneira) e a produtividade (um conjunto de categorias é considerado produtivo quando oferece resultados férteis) (BARDIN, 2010).

As proposições para a escolha de categorias da análise de conteúdo das reportagens tiveram como base os princípios gerais do jornalismo (KOVACH e ROSENSTIEL, 2003) e seus subgêneros científico e ambiental (BUENO, 1984). Sendo assim, foram estabelecidas cinco categorias: Precisão, Independência, Pluralidade, Contextualização e Sensibilização.

\section{Resultado da análise das matérias}

\section{Categoria sensibilização}

O intuito desta categoria é sensibilizar o público para a tomada de decisões esclarecidas, reunindo 0 princípio do jornalismo de apresentar o relevante de forma interessante, trazendo à tona sua função educativa. A primeira tabela refere-se à apresentação de informações da questão ambiental global para a compreensão do leitor, além de apenas noticiar $\mathrm{O}$ acontecimento. Em 98,15\% dos casos, o jornalista não sensibilizou o público para as questões globais, tornando improvável que ele tome atitudes clarificadas sobre $\mathrm{O}$ problema.

Tabela 1

\begin{tabular}{l|l|l}
\hline \multicolumn{3}{l}{ Categoria Sensibilização } \\
\hline A matéria buscou, além de noticiar & & \\
a questão ambiental tratada, & & \\
apresentar ao leitor informações & QTD & $\%$ \\
para a compreensão da questão & & \\
ambiental global? & & \\
\hline Sim & 1 & $1,85 \%$ \\
\hline Não & 53 & $98,15 \%$ \\
\hline
\end{tabular}

Fonte: Pesquisadora.

Scharf (2004) reitera que, por hábito ou discriminação, grande parte da mídia lida com a conjuntura ambiental como algo passageiro, espetacular, que chama atenção pelo que possui de encantador ou agressivo, e não por sua comoção concreta: econômica, política ou social. Desta forma, o sensacionalismo parece ocupar o lugar da apuração cuidadosa.

Fonseca (2004, p.137) considera que, "alimentar a neurose coletiva com previsões atemorizantes, além de promover a desinformação, pode de fato levar populações, instituições e governos a optar por soluções enganosas ou contraproducentes". O compromisso de apresentar o leitor ao contexto global traz a necessidade de traduzir termos técnicos que não são comumente conhecidos, e exatamente sobre isso que se refere a próxima tabela. 


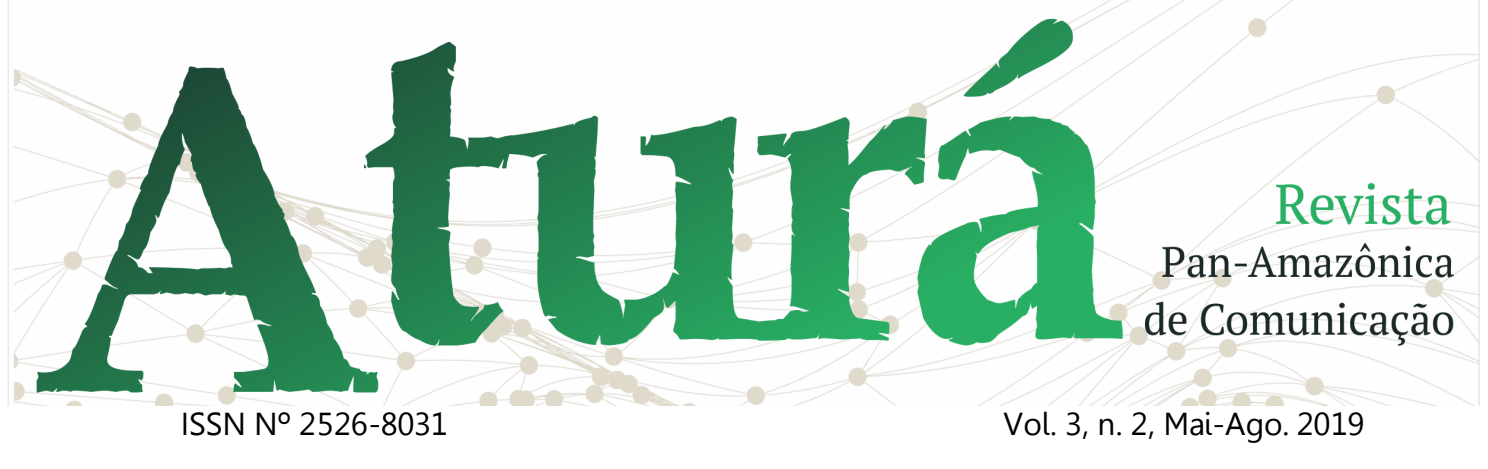

Antes da análise das reportagens, existiam apenas as opções 'sim' ou 'não', contudo, durante o estudo, percebeu-se a necessidade de adicionar uma terceira opção: 'não tem expressões pouco conhecidas referentes à temática ambiental', que rapidamente tornou-se líder no recolhimento de dados.

Tabela 2

\begin{tabular}{|c|c|c|}
\hline \multicolumn{3}{|l|}{ Categoria Sensibilização } \\
\hline $\begin{array}{l}\text { A matéria buscou traduzir para o } \\
\text { leitor termos e expressões } \\
\text { referentes a temática ambiental } \\
\text { pouco conhecidos? }\end{array}$ & QTD & $\%$ \\
\hline Sim & 5 & $9,26 \%$ \\
\hline Não & 9 & $16,67 \%$ \\
\hline $\begin{array}{l}\text { Não tem expressões pouco } \\
\text { conhecidas referentes à temática } \\
\text { ambiental }\end{array}$ & & $74,07 \%$ \\
\hline
\end{tabular}

Fonte: Pesquisadora.

O que se torna uma preocupação não é apenas a ausência da tradução dos termos ambientais desconhecidos, mas sim, o fato de que estes termos sequer estão sendo apresentados no decorrer das matérias. Então, como dizer que o jornalista está cumprindo seu papel em introduzir palavras difíceis no cotidiano da população se elas não aparecem no texto?

O jornal "Tribuna do Norte" falhou ao não promover um espaço para crescimento intelectual popular, além de,

em $16,67 \%$ das matérias, assumir que os termos utilizados eram de conhecimento geral e não requereriam explicação.

Ademais, ao não traduzir ou não apresentar estes termos, 0 jornalista usurpa o entendimento do povo a respeito das iniciativas políticas propostas para remediar ou evitar as mazelas ambientais, uma vez que o discurso governamental é, muitas vezes, adornado com expressões pouco conhecidas e falsas promessas.

Faz-se necessário que o jornalista tenha em mente que até mesmo as pessoas que não tem o menor interesse em aspectos ambientais devem alcançadas pelas informações da notícia. Belmonte (2004) afirma que o jornalismo no âmbito citadino é um instrumento de educação ambiental, onde os meios difusores de comunicação devem consumar campanhas públicas com o propósito de informar sobre os novos estilos de vida, expandindo esses espaços para ideias originais e resoluções inovadoras do governo.

Pensando na função educativa do jornalismo, a tabela seguinte foi voltada para a transmissão de conteúdo ambiental educativo aos leitores. Um percentual alarmante de $96,30 \%$ das matérias estudadas não trouxe qualquer conteúdo que instigasse o público a discutir sobre o assunto, contrariando o princípio do jornalismo ambiental da 


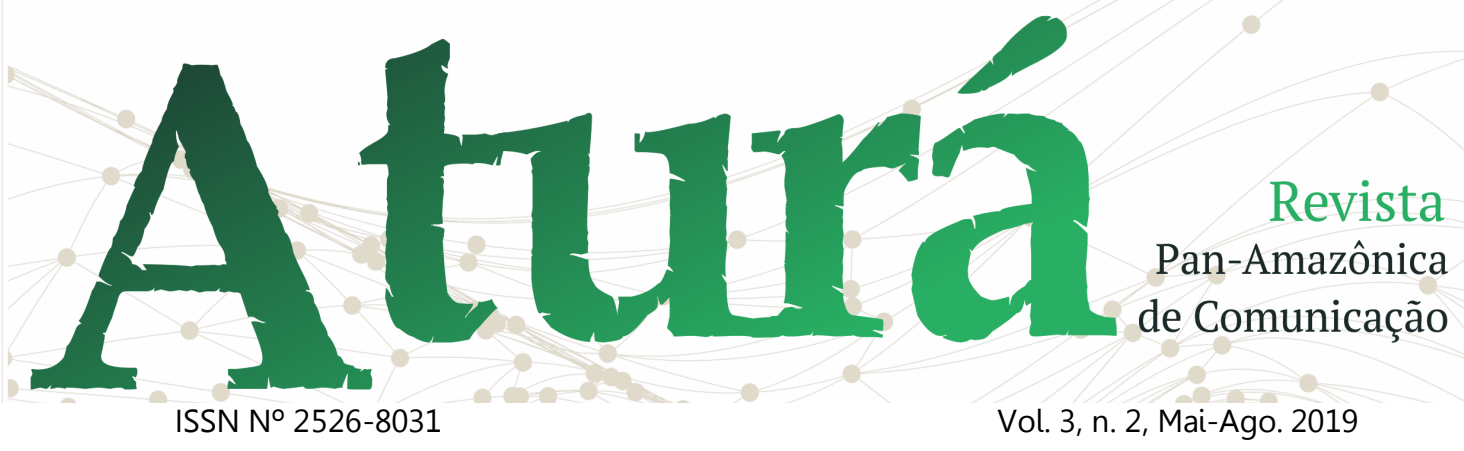

necessidade de oferecer condições para que o público participe do debate sobre - desenvolvimento sustentável, desempenhando uma função pedagógica no sentido de organizar conceitos, disseminar conhecimentos, informações e vivências.

Tabela 3

\begin{tabular}{|c|c|c|}
\hline Categoria Sensibilização & & \\
\hline $\begin{array}{l}\text { matéria buscou transmitir } \\
\text { conteúdos ambientais educativos } \\
\text { aos leitores? }\end{array}$ & ir & $\%$ \\
\hline$\overline{\text { Sim }}$ & 2 & $3,70 \%$ \\
\hline$\overline{\text { Não }}$ & 52 & $96,30 \%$ \\
\hline
\end{tabular}

Fonte: Pesquisadora.

Os números mostram que as informações divulgadas não atenderam o público com competência, já que o fator 'educação' não foi utilizado na construção textual. A grande maioria das reportagens simplesmente comunicou os fatos, sem se preocupar em contextualizar e fragmentando a notícia. Esse tipo de cobertura leva os jornalistas a ter um olhar míope sobre a questão ambiental, na qual não há preocupação com o contexto das ocorrências, ou seja, as pessoas terminam não sabendo 0 que aconteceu antes da notícia e suas prováveis consequências (SCHARF, 2004).

No que diz respeito a mostrar ao leitor como as questões tratadas os afetam ou como eles podem agir diante deles, a tabela inferiu que $42,59 \%$ das matérias abordaram tais conteúdos.

Tabela 4

\begin{tabular}{l|l|l}
\hline Categoria Sensibilização \\
\hline $\begin{array}{l}\text { A matéria buscou mostrar ao leitor } \\
\text { como as questões tratadas os }\end{array}$ & & \\
afetam ou como eles podem agir & QTD & $\%$ \\
diante deles? & & \\
\hline Sim & 23 & $42,59 \%$ \\
\hline Não & 31 & $57,41 \%$ \\
\hline \multicolumn{2}{c}{ Fonte: Pesquisadora. }
\end{tabular}

\section{Considerações finais}

A categoria Sensibilização procurou verificar se os conteúdos produzidos conscientizaram o público da importância dos problemas ambientais, além de inteirá-los para que tomem decisões mais esclarecidas diante destas adversidades e mostrar os efeitos globais destes fatos. Quanto à tradução de termos ou expressões referentes à temática ambiental, foi exposta a necessidade de criar uma nova opção para a subcategoria chamada 'não tem expressões pouco conhecidas da temática ambiental'.

A criação desta opção leva a refletir se o jornalista está cumprindo seu papel em introduzir palavras difíceis no cotidiano da população se elas sequer aparecem no texto. Quase em sua totalidade, as matérias não trouxeram 


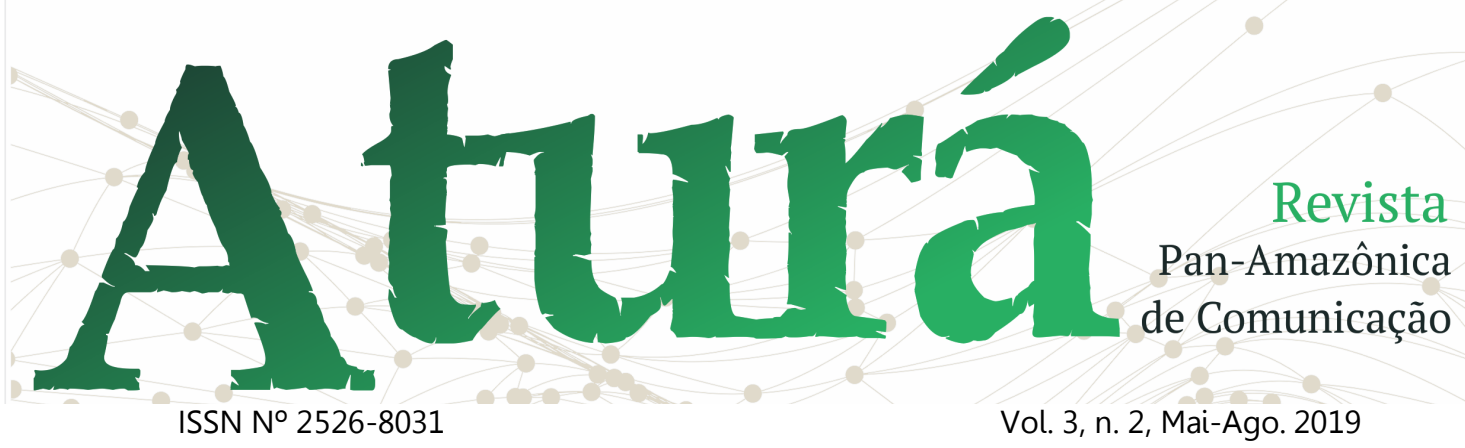

conteúdos educativos e contiveram-se a noticiar apenas os fatos. Referente à exposição de como os impasses ambientais afetam o público, os resultados são melhores, mas não chegam nem mesmo à metade.

O estudo referente aos dados das matérias de caráter ambiental no Nordeste expôs a necessidade do jornal "Tribuna do Norte" de examinar com afinco as publicações ambientais destinadas ao seu público, uma vez que todos os critérios positivos da sensibilização não chegaram à metade do resultado.

A mídia, de forma geral, precisa estar cada vez mais atenta à imprescindibilidade de informar com qualidade e elevar o nível intelectual do seu leitor, transformando-o em uma figura ativa na tomada de decisões em sociedade e em um ser argumentativo, carregado de críticas e opiniões.

\section{Referências}

$70 \%$ dos reservatórios do RN estão em situação crítica. Tribuna do Norte, Natal, 05 de novembro de 2017. Disponível em: $<$ http://www.tribunadonorte.com.br/notic ia/70-dos-reservata-rios-do-rn-esta-oem-situaa-a-o-cra-tica/396344>. Acesso em: 19 de janeiro de 2018.

ABASTECIMENTO d'água em Acari e Currais Novos entra em colapso. Tribuna do Norte, Natal, 28 de setembro de 2017.
Disponível

em: <http://www.tribunadonorte.com.br/notic ia/abastecimento-da-a-gua-em-acari-ecurrais-novos-entra-emcolapso/393400>. Acesso em: 01 de fevereiro de 2018.

ADUTORA emergencial deve operar este mês. Tribuna do Norte, Natal, 02 de fevereiro. Disponível em: $<$ http://www.tribunadonorte.com.br/notic ia/adutora-emergencial-deve-operareste-ma-s/404165>. Acesso em: 02 de fevereiro de 2018.

"AQUAPONIA" garante produção de alimentos com baixo uso de água. Tribuna do Norte, Natal, 31 de outubro de 2017. Disponível em: <http://www.tribunadonorte.com.br/notic ia/a-aquaponiaa-garante-produa-a-o-dealimentos-com-baixo-uso-de-a-

gua/396029>. Acesso em: 19 de janeiro de 2018.

APESAR das chuvas, RN ainda tem 15 cidades em colapso. Tribuna do Norte, Natal, 24 de fevereiro de 2018. Disponível em:

$<$ http://www.tribunadonorte.com.br/notic ia/apesar-das-chuvas-rn-ainda-tem-15cidades-em-colapso/405941>. Acesso em: 27 de fevereiro de 2018.

BARDIN, Laurence. Análise de Conteúdo. Lisboa/Portugal: Edições 70 LDA, 2010.

BELMONTE, Roberto Villar. Menos catástrofes e mais ecojornalismo. In: BOAS, Sérgio Vilas. Formação \& 


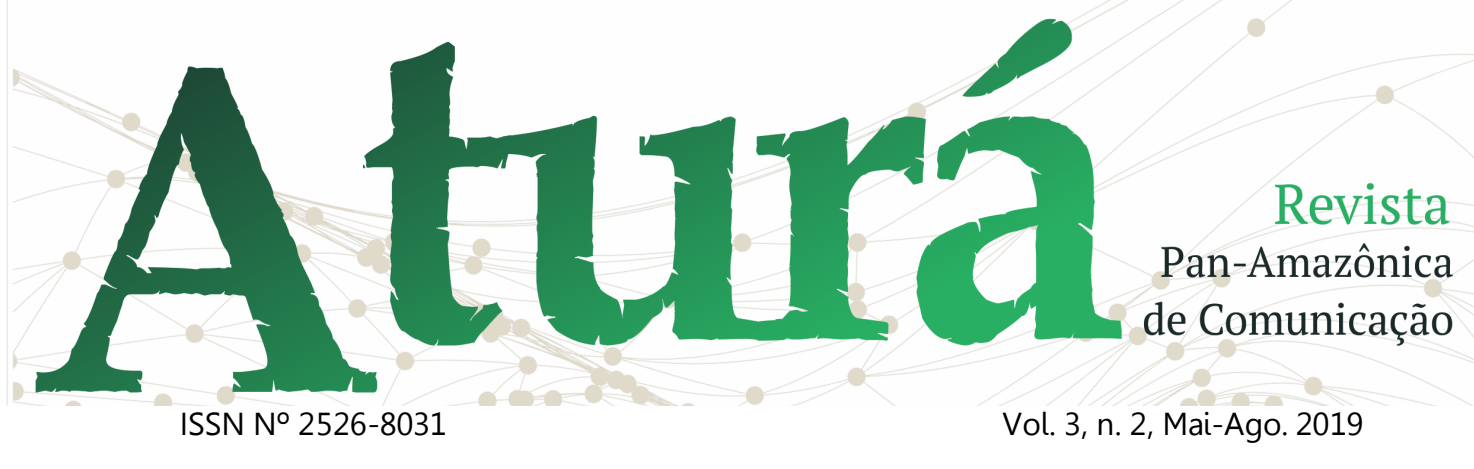

informação ambiental: jornalismo para iniciados e leigos. São Paulo: Summus, 2004

BUENO, Wilson da Costa. Comunicação, jornalismo e meio ambiente: teoria e pesquisa. São Paulo: Majoara, 2007.

Jornalismo científico no Brasil: o compromisso de uma prática independente. São Paulo, 1984.

CÂMARA pode votar nova lei de licenciamento ambiental nas próximas semanas. Tribuna do Norte, Natal, 13 de março de 2018. Disponível em: <http://www.tribunadonorte.com.br/notic ia/ca-mara-pode-votar-nova-lei-delicenciamento-ambiental-nas-pra-ximassemanas/407456>. Acesso em: 14 de março de 2018.

CECl, Mariana. Chuvas deixam famílias desabrigadas. Tribuna do Norte, Natal, 20 de fevereiro de 2018. Disponível em: <http://www.tribunadonorte.com.br/notic ia/chuvas-deixam-fama-lias-

desabrigadas/405470>. Acesso em: 21 de fevereiro de 2018.

CECl, Mariana. Falta d'água no sertão limita oportunidade de trabalho e renda. Tribuna do Norte, Natal, 02 de fevereiro de 2018. Disponível em: <http://www.tribunadonorte.com.br/notic ia/falta-da-a-gua-no-serta-o-limitaoportunidades-de-trabalho-erenda/404083>. Acesso em: 02 de fevereiro de 2018.

CHAPARRO, Manoel Carlos. Linguagem dos conflitos. Coimbra: Minerva, 2001.

CHUVAS amenizam seca, mas impactos hidrológicos continuam. Tribuna do Norte, Natal, 21 de fevereiro de 2018. Disponível em: <http://www.tribunadonorte.com.br/notic ia/chuvas-amenizam-seca-mas-impactoshidrola-gicos-continuam/405613>. Acesso em: 21 de fevereiro de 2018.

CHUVA de $32,6 \mathrm{~mm}$ em uma hora alaga vias em Natal. Tribuna do Norte, Natal, 02 de março de 2018. Disponível em: <http://www.tribunadonorte.com.br/notic ia/chuva-de-32-6mm-em-uma-horaalaga-vias-em-natal/406404>. Acesso em: 02 de março de 2018.

CHUVAS elevam volume da barragem Armando Ribeiro. Tribuna do Norte, Natal, 03 de março de 2018. Disponível em:

$<$ http://www.tribunadonorte.com.br/notic ia/chuvas-elevam-volume-da-barragemarmando-ribeiro/406523>. Acesso em: 05 de março de 2018.

CHUVAS provocam transtornos e Defesa Civil está em alerta. Tribuna do Norte, Natal, 17 de fevereiro de 2018. Disponível em:

<http://www.tribunadonorte.com.br/notic ia/chuvas-provocam-transtornos-edefesa-civil-esta-em-alerta/405378>. Acesso em: 21 de fevereiro de 2018.

COMPORTAS da barragem de Poço Branco são abertas. Tribuna do Norte, 


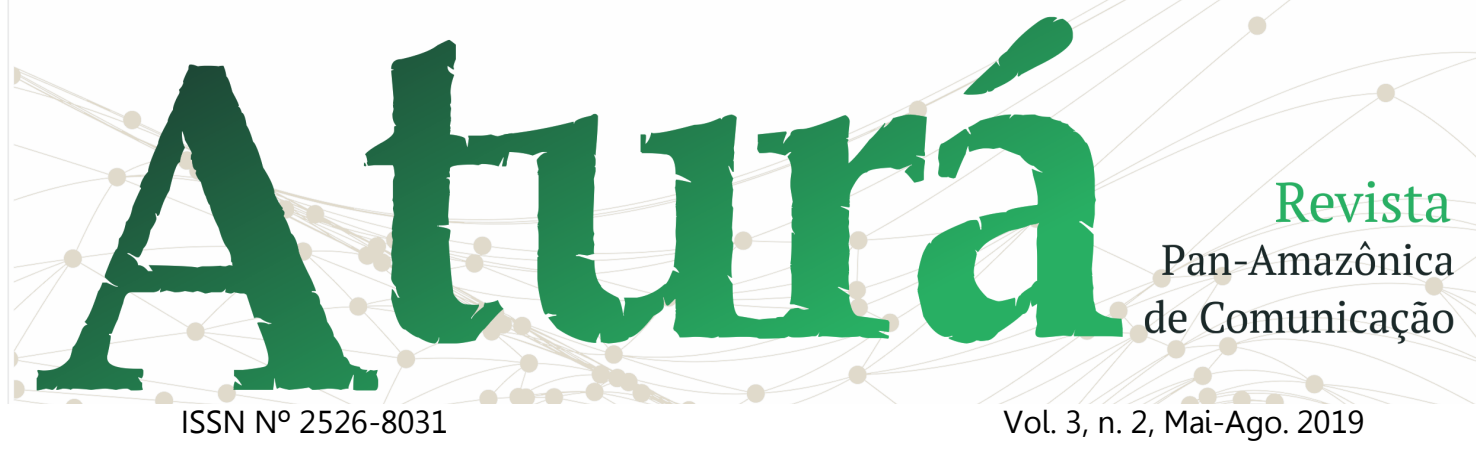

Natal, 17 de novembro de 2017. Disponível em: $<$ http://www.tribunadonorte.com.br/notic ia/comportas-da-barragem-de-poa-obranco-sa-o-abertas/397430>. Acesso em: 19 de janeiro de 2018.

"DESAFIO é criar condições para abastecer famílias e impulsionar 0 desenvolvimento". Tribuna do Norte, 29 de outubro de 2017. Disponível em: <http://www.tribunadonorte.com.br/notic ia/a-desafio-a-criar-condia-a-es-paraabastecer-fama-lias-e-impulsionar-odesenvolvimentoa/395859>. Acesso em: 19 de janeiro de 2018.

ESCASSEZ de água faz consumo cair no Rio Grande do Norte. Tribuna do Norte, Natal, 21 de março de 2018. Disponível em:

<http://www.tribunadonorte.com.br/notic ia/escassez-de-a-gua-faz-consumo-cairno-rio-grande-do-norte/408100>. Acesso em: 21 de março de 2018.

ESTIAGEM de 2017 pode levar a reajustes de mais de 10\% para energia em 2018. Tribuna do Norte, Natal, 07 de janeiro de $2018 . \quad$ Disponível em: <http://www.tribunadonorte.com.br/notic ia/estiagem-de-2017-pode-levar-areajustes-de-mais-de-10-para-energiaem-2018/401754>. Acesso em: 05 de fevereiro de 2018.

FALTA de verba agrava crise hídrica. Tribuna do Norte, Natal, 27 de março de $2018 . \quad$ Disponível em: <http://www.tribunadonorte.com.br/notic

ia/falta-de-verba-agrava-crise-hadrica/408639>. Acesso em: 31 de março de 2018.

FONSECA, André Azevedo da. Água de fonte só: a magnitude do problema em uma experiência concreta. In: BOAS, Sérgio Vilas. Formação \& informação ambiental: jornalismo para iniciados e leigos. São Paulo: Summus, 2004.

GOMES, Luiz Henrique. Em dois anos, RN recebeu $16 \%$ da verba solicitada para obras hídricas. Tribuna do Norte, Natal, 20 de setembro de 2017. Disponível em: $<$ http://www.tribunadonorte.com.br/notic ia/em-dois-anos-rn-recebeu-16-daverba-solicitada-para-obras-hadricas/392599>. Acesso em: 01 de fevereiro de 2018.

GOMES, Luiz Henrique. Poço Branco vive conflito por água. Tribuna do Norte, Natal, 28 de outubro de 2017. Disponível em:

<http://www.tribunadonorte.com.br/notic ia/poa-o-branco-vive-conflito-por-agua/395799>. Acesso em: 19 de janeiro de 2018.

GOVERNO do RN pleiteia em Brasília R\$ 88 milhões para medidas emergenciais de enfrentamento à seca. Tribuna do Norte, Natal, 18 de setembro de 2017. Disponível em: $<$ http://www.tribunadonorte.com.br/notic ia/governo-do-rn-pleiteia-em-brasa-lia-r88-milha-es-para-medidas-emergenciaisde-enfrentamento-a-seca/392098>. Acesso em: 01 de fevereiro de 2018. 


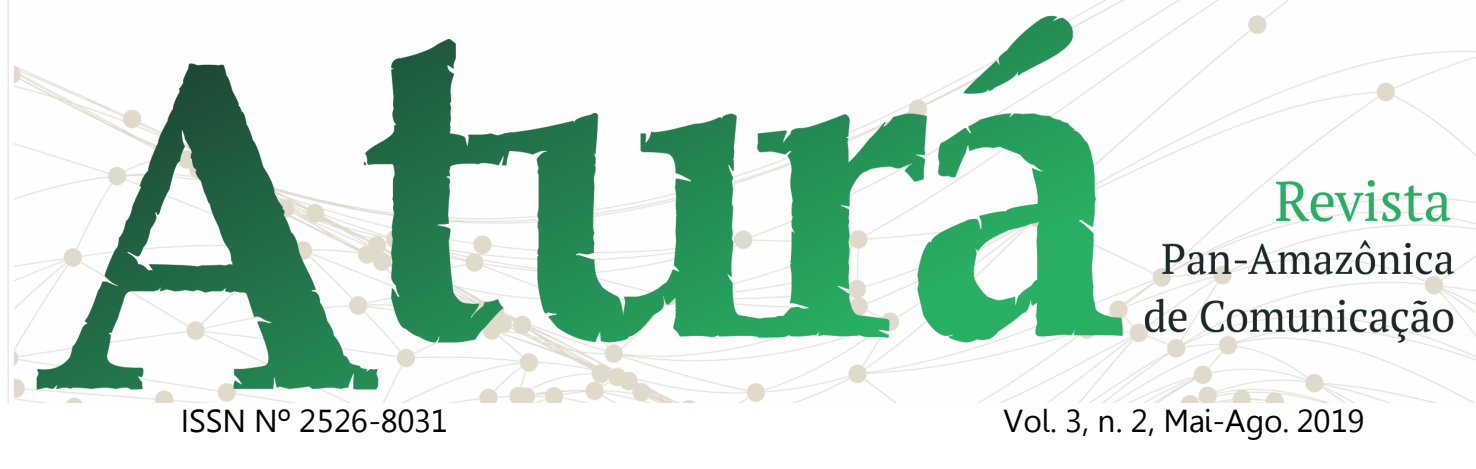

GOVERNO e municípios discutem ações para amenizar efeitos da seca do Piranhas-Açu. Tribuna do Norte, Natal, 13 de setembro de 2017. Disponível em: <http://www.tribunadonorte.com.br/notic ia/governo-e-munica-pios-discutem-aaa-es-para-amenizar-efeitos-da-seca-dopiranhas-aa-u/392013>. Acesso em: 01 de fevereiro de 2018.

GOVERNO prorroga, pela $10^{\mathrm{a}}$ vez, emergência pela seca. Tribuna do Norte, Natal, 18 de março de 2018. Disponível em:

<http://www.tribunadonorte.com.br/notic ia/governo-prorroga-pela-10a-vez-

emerga-ncia-pela-seca/407895>. Acesso em: 20 de março de 2018.

IVANISSEVICH, Alícia. Como popularizar a ciência com responsabilidade e sem sensacionalismo. In: BOAS, Sérgio Vilas. Formação \& informação científica: jornalismo para iniciados e leigos. São Paulo: Summus, 2005.

KOVACH, Bill; ROSENSTIEL, Tom. Os elementos do jornalismo: o que os jornalistas devem saber e o público exigir. São Paulo: Geração, 2003.

LEFF, E. Ecologia, capital e cultura: a territorialização da racionalidade ambiental. Petrópolis - RJ, 2009, p. 47.

LIBERAÇÃO de água na barragem Poço Branco é adiada. Tribuna do Norte, Natal, 08 de novembro de 2017. Disponível em: <http://www.tribunadonorte.com.br/notic ia/liberaa-a-o-de-a-gua-na-barragem- poa-o-branco-a-adiada/396638>. Acesso em: 19 de janeiro de 2018.

MAZDA, Aura. Falta verba para construir adutoras alternativas. Tribuna do Norte, Natal, 17 de novembro de 2017. Disponível em: <http://www.tribunadonorte.com.br/notic ia/falta-verba-para-construir-adutorasalternativas/397235>. Acesso em: 19 de janeiro de 2018.

MAZDA, Aura. Moradores da Mor Gouveia cobram drenagem. MP pede solução para evitar alagamentos. Tribuna do Norte, Natal, 03 de março de 2018. Disponível em:

$<$ http://www.tribunadonorte.com.br/notic ia/moradores-da-mor-gouveia-cobramdrenagem-mp-pede-solua-a-o-paraevitar-alagamentos/406529>. Acesso em: 05 de março de 2018.

MAZDA, Audra. Seca: Faltam ações preventivas. Tribuna do Norte, Natal, 25 de outubro de 2017. Disponível em: <http://www.tribunadonorte.com.br/notic ia/seca-faltam-aa-a-es-

preventivas/395519>. Acesso em: 01 de fevereiro de 2018.

MAZDA, Audra. Seminário vai debater crise hídrica. Tribuna do Norte, Natal, 24 de outubro de 2017. Disponível em: <http://www.tribunadonorte.com.br/notic ia/semina-rio-vai-debater-crise-hadrica/395429>. Acesso em: 01 de fevereiro de 2018. 


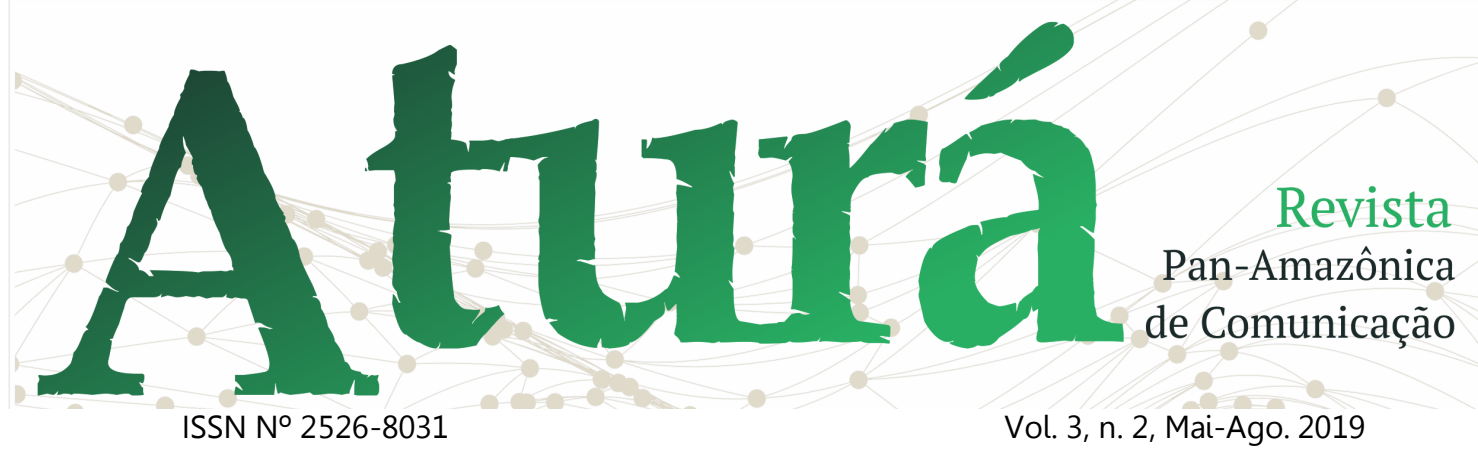

MELO, José Marques de; ASSIS, Francisco de. Gêneros Jornalísticos no Brasil. São Bernardo do Campo: Universidade Metodista de São Paulo, 2010.

MESMO com chuvas, a crise hídrica permanece. Tribuna do Norte, Natal, 23 de janeiro de 2018. Disponível em: $<$ http://www.tribunadonorte.com.br/notic $\mathrm{ia/mesmo-com-chuvas-crise-ha-drica-}$ permanece/403149>. Acesso em: 02 de fevereiro de 2018.

MI libera $R \$ 39,3$ milhões para obras de Oiticica. Tribuna do Norte, Natal, 18 de novembro de 2017. Disponível em: <http://www.tribunadonorte.com.br/notic ia/mi-libera-r-39-3-milha-es-para-obrasde-oiticica/397441>. Acesso em: 19 de janeiro de 2018.

Ministério do Meio Ambiente. Acordo de Paris. Disponível em: <http://www.mma.gov.br/clima/convenca o-das-nacoes-unidas/acordo-de-paris $>$. Acesso em: Dez/2017.

NOBLAT, Ricardo. O que é ser jornalista? São Paulo: Contexto, 2004.

"NÓS não conseguimos ofertar água para a demanda do RN". Tribuna do Norte, Natal, 05 de novembro de 2017. Disponível em: <http://www.tribunadonorte.com.br/notic ia/na-s-na-o-conseguimos-ofertar-a-guapara-a-demanda-do-rn/396345>. Acesso em: 19 de janeiro de 2018.
OBRAS da adutora emergencial que atenderá Mossoró e Assú está em andamento. Tribuna do Norte, Natal, 05 de janeiro de 2018. Disponível em: <http://www.tribunadonorte.com.br/notic ia/obras-da-adutora-emergencial-queatendera-mossora-e-assao-esta-emandamento/401582 >. Acesso em: 19 de janeiro de 2018.

PENA, Felipe. Teoria do jornalismo. São Paulo: Contexto, 2005.

PGJ defende responsabilização de quem utilizar água inadequadamente. Tribuna do Norte, Natal, 30 de outubro de 2017. Disponível em: <http://www.tribunadonorte.com.br/notic ia/pgj-defende-responsabilizaa-a-o-dequem-utilizar-a-guainadequadamente/395938>. Acesso em: 19 de janeiro de 2018.

PLANO de Segurança Hídrica precisa da ação dos munícipios. Tribuna do Norte, Natal, 31 de outubro de 2017. Disponível em:

<http://www.tribunadonorte.com.br/notic ia/plano-de-segurana-a-ha-drica-precisada-aa-a-o-dos-munica-pios/396032>. Acesso em: 19 de janeiro de 2018.

POPULAÇÃO pode ajudar na prevenção de alagamentos. Tribuna do Norte, Natal, 17 de fevereiro de 2018. Disponível em: <http://www.tribunadonorte.com.br/notic ia/populaa-a-o-pode-ajudar-na-prevenaa-o-de-alagamentos/405314>. Acesso em: 21 de fevereiro de 2018. 


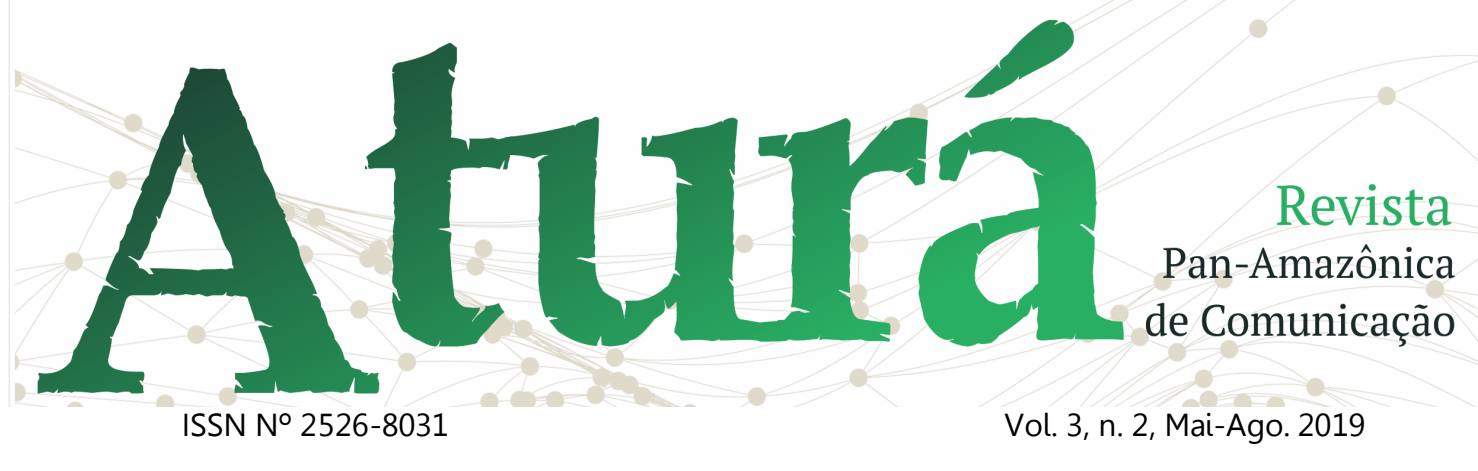

PREFEITURA de Parnamirim elabora plano emergencial. Tribuna do Norte, Natal, 20 de fevereiro de 2018. Disponível em: <http://www.tribunadonorte.com.br/notic ia/prefeitura-de-parnamirim-elaboraplano-emergencial/405469>. Acesso em: 21 de fevereiro de 2018.

PREJUÍZOS da seca do RN superaram R\$ 4 bilhões. Tribuna do Norte, Natal, 21 de outubro de 2017. Disponível em: <http://www.tribunadonorte.com.br/notic ia/prejua-zos-da-seca-no-rn-superam-r4-bilha-es/395227>. Acesso em: 01 de fevereiro de 2018.

RN busca R\$ 340 milhões para Plano de Segurança Hídrica. Tribuna do Norte, Natal, 05 de novembro de 2017. Disponível em: <http://www.tribunadonorte.com.br/notic ia/rn-busca-r-340-milha-es-para-planode-segurana-a-ha-drica/396348>. Acesso em: 19 de janeiro de 2018.

RN já tem 16 cidades em colapso de abastecimento. Tribuna do Norte, Natal, 11 de janeiro de 2018. Disponível em: <http://www.tribunadonorte.com.br/notic ia/rn-ja-tem-16-cidades-em-colapso-deabastecimento/402053>. Acesso em: 19 de janeiro de 2018 .

RN pede liberação de $\mathrm{R} \$ 118$ milhões para obras hídricas e Operação Pipa. Tribuna do Norte, Natal, 21 de setembro de 2017. Disponível em: <http://www.tribunadonorte.com.br/notic ia/rn-pede-liberaa-a-o-de-r-118-milhaes-para-obras-ha-dricas-e-operaa-a-o- pipa/392715>. Acesso em: 05 de fevereiro de 2018.

RN tem 18 açudes em volume morto. Tribuna do Norte, Natal, 14 de setembro de 2017. Disponível em: <http://www.tribunadonorte.com.br/notic ia/rn-tem-18-aa-udes-em-volume-

morto/392038>. Acesso em: 01 de fevereiro de 2018. Acesso em: 01 de fevereiro de 2018.

SANTOS, J.M. O que é análise de conteúdo. São Paulo: Summus, 1997.

SECA reduz produção de tilápia no RN. Tribuna do Norte, Natal, 15 de outubro de 2017. Disponível em: <http://www.tribunadonorte.com.br/notic ia/seca-reduz-produa-a-o-de-tilapia-norn/394685>. Acesso em: 01 de fevereiro de 2018.

"SEM chuva não tinha nem o que plantar ou comer". Tribuna do Norte, Natal, 01 de fevereiro de 2018. Disponível em: <http://www.tribunadonorte.com.br/notic ia/sem-chuva-na-o-tinha-nem-o-queplantar-ou-comer/404006>. Acesso em: 01 de fevereiro de 2018.

SILVA, Yuno. Barragem Armando Ribeiro entra em volume morto. Tribuna do Norte, Natal, 05 de janeiro de 2018. Disponível em: <http://www.tribunadonorte.com.br/notic ia/barragem-armando-ribeiro-entra-emvolume-morto/401528>. Acesso em: 19 de janeiro de 2018. 


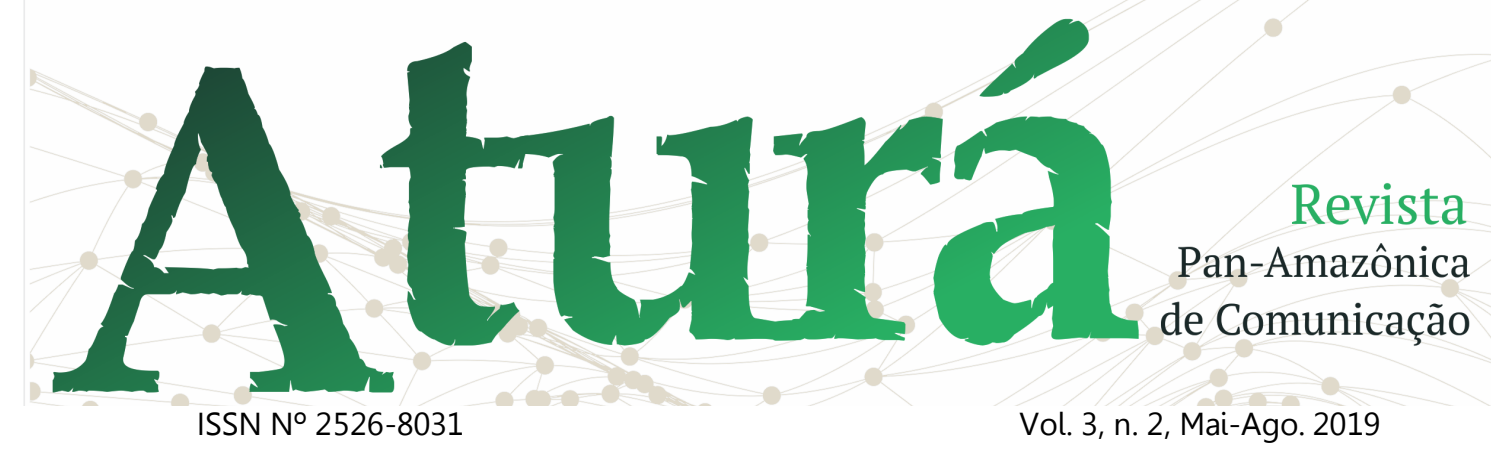

SILVA, Yuno. Caern estuda projeto alternativo para reduzir captação de água na Armando Ribeiro. Tribuna do Norte, Natal, 24 de outubro de 2017. Disponível em:

<http://www.tribunadonorte.com.br/notic ia/caern-estuda-projeto-alternativo-parareduzir-captaa-a-o-de-a-gua-naarmando-ribeiro/395418>. Acesso em: 01 de fevereiro de 2018.

SILVA, Yuno. "Faltam propostas para utilizar as águas da transposição". Tribuna do Norte, Natal, 10 de setembro de 2017. Disponível em: <http://www.tribunadonorte.com.br/notic ia/a-faltam-propostas-para-utilizar-as-aguas-da-transposia-a-oa/391665>.

Acesso em: 01 de fevereiro de 2018.

SILVA, Yuno. Maré alta invade ruas e imóveis no município de Caiçara do Norte. Tribuna do Norte, Natal, 02 de março de 2018. Disponível em: <http://www.tribunadonorte.com.br/notic ia/mara-alta-invade-ruas-e-ima-veis-nomunica-pio-de-caia-ara-donorte/406541>. Acesso em: 05 de março de 2018.

SILVA, Yuno. Rios Potengi e Pitimbu sofrem com poluição e assoreamento. Tribuna do Norte, Natal, 29 de outubro de 2017. Disponível em: <http://www.tribunadonorte.com.br/notic ia/rios-potengi-e-pitimbu-sofrem-compoluia-a-o-e-assoreamento/395847>. Acesso em: 02 de fevereiro de 2018.
SILVA, Yuno. Santana do Matos fica sem água. Tribuna do Norte, Natal, 24 de novembro de 2017. Disponível em: <http://www.tribunadonorte.com.br/notic ia/santana-do-matos-fica-sem-agua/397915>. Acesso em: 05 de fevereiro de 2018.

SOBE para 16 o número de cidades do RN em colapso de abastecimento. Tribuna do Norte, Natal, 10 de janeiro de $2018 . \quad$ Disponível em: <http://www.tribunadonorte.com.br/notic ia/sobe-para-16-o-naomero-de-cidadesdo-rn-em-colapso-deabastecimento/402023>. Acesso em: 19 de janeiro de 2018.

SCHARF, Regina. Economia sustentável é utopia, contradição ou lucro certo? In: BOAS, Sérgio Vilas. Formação \& informação ambiental: jornalismo para iniciados e leigos. São Paulo: Summus, 2004.

"TEMOS 1.400 cidades em situação de emergência". Tribuna do Norte, Natal, 31 de outubro de 2017. Disponível em: <http://www.tribunadonorte.com.br/notic ia/a-temos-1-400-cidades-em-situaa-a-ode-emerga-nciaa/396030>. Acesso em: 19 de janeiro de 2018.

"TEMOS água para mais um ano; falta a infraestrutura". Tribuna do Norte, Natal, 02 de fevereiro de 2018. Disponível em: <http://www.tribunadonorte.com.br/notic ia/temos-a-gua-para-mais-um-ano-faltaa-infraestrutura/404164>. Acesso em: 02 de fevereiro de 2018. 